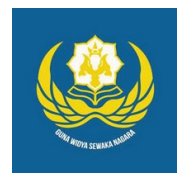

Jurnal Analogi Hukum

Journal Homepage: https://ejournal.warmadewa.ac.id/index.php/analogihukum

\title{
Penerapan Pasal 1320 Kuh Perdata Terhadap Tanggung Jawab Penjual Dalam Perjanjian Jual Beli Barang Melalui Media Internet
}

\author{
I Komang Mahesa Putra*, Ni Luh Made Mahendrawati dan Desak Gde Dwi Arini \\ Fakultas Hukum, Universitas Warmadewa, Denpasar, Bali-Indonesia \\ *mahes.p@gmail.com
}

\begin{abstract}
How To Cite:
Putra, I, K, M., Mahendrawati, N, L, M., Arini, D, G, D. (2020). Penerapan Pasal 1320 Kuh Perdata Terhadap Tanggung Jawab Penjual Dalam Perjanjian Jual Beli Barang Melalui Media Internet. Jurnal Analogi Hukum. 2(1). 73-77. Doi: http:// dx.doi.org/10.22225/.2.1.1623.73-77
\end{abstract}

\begin{abstract}
This trade activity by utilizing internet media is known as electronic commerce, or abbreviated as ecommerce. Regarding the relevance of existing legislation with the need for regulations in buying and selling transactions through internet media, especially the seller's responsibility. The formulation of the problem in this writing is how the legal protection for the parties in the sale and purchase agreement through the internet media and how the seller's responsibility in the sale and purchase agreement based on article 1320 of the Civil Code. The author uses the type of normative legal research and the problem approach used is the basis of the conceptual approach and legislation. The agreement needed to give birth to an agreement mandated in Article 1320 of the Civil Code is considered to have been reached if the statement of one party was received by the other party. In summary, an agreement is considered to have taken place when one of the parties agreed. The government should provide more stringent supervision for the parties who carry out this electronic transaction, namely by conducting a registration of all activities involving public interest in electronic traffic.
\end{abstract}

Keywords: Sale and Purchase Agreement, Seller responsibilities, e-commerce

\begin{abstract}
Abstrak-Kegiatan yang menggunakan elektronik komersil sudah digandrungi beberapa orang dengan penggunaan yang semakin meningkat dengan pesat setiap tahunnya atau disingkat e-commerce. Berkaitan dengan relevansi peraturan perundang-undangan yang sudah ada dengan kebutuhan akan peraturan dalam transaksi jual beli melalui media internet terutama pertanggungjawaban penjual. Rumusan masalah dalam penulisan ini adalah bagaimana perlindungan hukum bagi para pihak dalam perjanjian jual beli melalui media internet dan Bagaimana tanggung jawab penjual dalam perjanjian jual beli barang berdasarkan pasal 1320 KUH Perdata. Penulis menggunakan tipe penelitian hukum normative dan pendekatan masalah yang digunakan adalah dasar pendekatan konseptual dan Peraturan perundang-undangan. Persetujuan antara kedua orang yang menjalin suatu hubungan keperdataan di anggap telah sah apabila keduanya setuju. Ringkasnya, suatu perjanjian dianggap telah terjadi pada saat salah satu pihak menyatakan sepakat. Pemerintah seyogyanya memberikan pengawasan yang lebih ketat lagi bagi para pihak yang melakukan transaksi elektronik ini yaitu dengan jalan melakukan suatu pendaftaran terhadap segala kegiatan yang menyangkut kepentingan umum didalam lalu lintas elektronik.
\end{abstract}

Kata Kunci: Perjanjian jual beli, tanggung jawab penjual, e-commerce

\section{Pendahuluan}

Dalam era pembangunan yang serba modern pada zaman sekarang ini era globalisasi membawa efek yang sangat berpengaruh, terutama dalam bidang tekonologi dan komunikasi. Tidak dapat dipungkiri lagi tekonolgi berkembang dengan sangat pesat. Prilaku masyarakatnya pun ikut mengalami perubahan yang signifikan. Sedemikian cepat proses berlangsungnya perubahan-perubahan yang terjadi mengakibatkan tidak adanya batas suatu hubungan sosial.

Berbagai situs menawarkan berbagai jenis barang yang setiap orang berpikir ingin membeli walaupun terkadang yang diharapkan tidak sesuai kenyataan. Perkembangan dunia 
yang cukup pesat dalam elektronik menyebabkan manusia harus pintar-pintar dalam menggunakannya. Diharapkan memeberikan manfaat yang positif didalam kehidupan seperti misalnya melakukan bisnis hanya lewat telephone ataupun hanya duduk di depan layar monitor mendapatkan hasil yang maksimal (Barkatullah \& Prasetyo, 2005).

Teknik perdagangan menggunakan media internet sebagai untuk bertransaksi merupakan suatu fasilitas yang ada pada saat ini dan banyak digunakan oleh orang yang tidak mengenal batas usia. Perkembangan media online yang sangat cepat ini memberikan kemudahan bagi setiap individu untuk melakukan suatu kegiatan yang bisa dilakukan dimana saja kapanpun dan oleh siapa pun. Contohnya bila dulu kita harus mengunjungi suatu tempat untuk membeli barang, sekarang kita hanya dengan membuka dan menjelajah di media digital kita bisa melakukan pemesanan dan memilih barang tanpa harus membuang waktu dan tenaga lebih banyak untuk mencari apa yang kita inginkan.

Namun tidak semua barang dapat di lakukan melalui transaksi di media online, ada beberapa barang yang ditidak bisa dijual maupun dibeli. Hanya benda atau barangbarang yang bergerak saja, jika seseorang ingin menjual tanah itu mustahil dilaksanakan sebab itu mempunyai surat atas tanah tersebut yang bersifat pribadi dan harus dilakukan secara empat mata. Seperti yang kita tahu hanya benda yang dapat dilakukan transaksi seperti, mobil, motor, baju, perabotan rumah tangga dan sebagainya.

Pada zaman sekarang ini banyak orang yang mengkhususkan dirinya dengan cara membuat suatu kelompok perdangangan yang menjual hasil produksi yang sama. Apapula kelemahan dan keburukan dari proses ini seperti konsumen yang tidak jujur dia memesan barang namun sampai barang dating dia tidak melakukan pembayaran dan itu sudah melanggar kesepakatan yang telah dibuat sejak awal. Bagi setiap individu yang merasa dirugikan atas perbuatan yang tidak menyenangkan tersebut, bagi pihak yang dirugikan dapat menggugat yang bersangkutan (Barkatullah \& Prasetyo, 2005).

Dalam dunia internasional umumnya kegiatan perdagangan lewat dunia maya seperti ini menimbulkan berbagai macam masalah dan manfaat. Gaya hidup seperti ini sudah lumrah dilaksanakan di luar negeri terutama pada negara maju. Di Indonesia kegiatan pemasaran dengan menggunakan bantuan internet dirasakan dapat membantu dalam segala bidang kehidupan. Namun hal itu kembali kepada individu masing-masing orang karena tidak semua orang mempunyai keinginan baik dalam menggunakan fasilitas yang canggih sperti ini (Barkatullah \& Prasetyo, 2005).

Banyak permasalah yang terjadi mulai dari pembohongan publik seperti yang beredar saat ini banyaknya hoax yang muncul ke dunia globalisasi seperti ini. Tidak ada salahnya bila kita melakukan pembelian lewat cara menjelajah di dunia maya asalkan niat kita benar dan tulus jangan sampai ada yang dirugikan akibat kesalahan dari kita.

Lain halnya dengan si pembeli ini dalam sisi yang satunya sebagai penjual harus benar memberikan informasi apa yang di jual dan di perdagangkan. Jangan sampai apa yang terlihat di layar handphone ataupun komputer lain dengan aslinya, apabila terjadi seperti itu berarti itu sudah melakukan suatu penipuan. Sekarang ini semua hak kepemilikan dan pencipataan sudah dapat perlindungan hukum dengan dikeluarkannya hak cipta suatu hasil karya dan hak paten.

Apabila dalam prosesnya terjadi pertikaian antara kedua belah pihak dalam dunia yang modern ini sudah ada UU ITE yang diperuntukan untuk pengguna media sosial. Berbagai jenis peraturan hukum diterbitkan oleh pemerintah guna melindungi hak-hak pihak yang ada didalam proses transaksi ini.

Penelitian serupa telah dilakukan oleh (Agusta, 2010) yang berfokus untuk mengetahui tanggungjawab penjual dalam perjanjian jual beli barang melalui media internet dan penyelesaian dalam hal terjadi sengketa antara pembeli dengan penjual dalam jual beli melalui media internet. Hasil penelitian ini menunjukkan bahwa tanggung jawab penjual terhada pembeli dalam hal adanya cacat tersembunyi dalam jual beli laptop melalui internet, maka tidak semua cacat tersembunyi dapat ditanggung oleh pihak penjual, karena hanya masalah yang berhubungan dengan kerusakan sebagai akibat cacat bahan atau kesalahan pengerjaan saja yang dapat ditanggung dalam jangka waktu garansi. Pada kasus yang telah diuraikan, pihak penjual hanya bersedia memperbaiki laptop tersebut, tanpa bersedia mengganti dengan yang baru, namun pihak penjual akan membebaskan dari biaya service. Meskipun dernikian, pembeli tetap meminta agar laptop tersebut diganti dengan yang baru. Selain itu (Safi'i \& Budiwati, 2018) juga melakukan penelitian serupa yang bertujuan untuk mengetahui tanggung jawab 
masing-masing pihak dalam jual beli online dan perlindungan konsumen dalam jual beli online. Hasil penelitian ini menunjukkan bahwa tanggung jawab penjual adalah melakukan penjualan dengan jujur dan memberikan kompensasi ganti rugi atas kerugian konsumen. Dan tanggung jawab pembeli adalah memberikan bayaran harga sesuai kesepakatan bersama. Kemudian perlindungan konsumen dalam jual beli online adalah yaitu mendapatkan barang atau jasa yang sesuai kondisi, mendapatkan informasi yang jelas mengenai barang, mendapatkan perlindungan sebagaimana mestinya serta mendapat ganti kerugian. Hak untuk mendapatkan advokasi, perlindungan, dan upaya penyelesaian sengketa perlindungan konsumen secara patut.

Berdasarkan dari uraian latar belakang diatas adapun rumusan masalah yang akan penulis bahas, yaitu: Bagaimana perlindungan hukum bagi para pihak dalam perjanjian jual beli melalui media internet?, Bagaimana tanggung jawab penjual dalam perjanjian jual beli barang berdasarkan pasal $1320 \mathrm{KUH}$ Perdata?

\section{Metode}

Dalam penelitian ini penulis menggunakan metode penelitian hukum normatif yaitu dengan cara melakukan pengkajian terhadap bahan hukum dari literatur. Dalam penelitian ini penulis menggunakan pendekatan masalah yaitu pendekatan secara perundang-undangan dan pendekatan secara konseptual. Pendekatan perundang-undangan ialah suatu pendekatan dimana suatu peraturan perundangan-undangan dikaji lebih dalam dan khusus peraturan perundang-undangan tersebut juga berhubungan dengan permasalahan yang ada. Sedangkan pendekatan konseptual merupakan suatu pendekatan yang didalam ilmu hukum ada dan berkembang pemikiran dan doktrin para sarjana.

Adapun sumber bahan hukum yang digunakan penulis akan digunakan yaitu bersumber dari penelitian dan kepustakaan, berupa: Bahan hukum primer adalah bahan hukum yang sifatnya mengikat berupa peraturan perundang-undangan yang berlaku dan ada kaitannya dengan permasalahan yang dibahas meiputi: Undang-Undang Dasar Negara Republik Indonesia Tahun 1945; Kitab Undang -Undang Hukum Perdata. Bahan hukum sekunder adalah bahan hukum yang sifatnya menjelaskan bahan hukum primer, dimana bahan hukum sekunder berupa buku literatur, hasil karya sarjana untuk memperluas wawasan penulis mengenai bidang penulisan. Bahan hukum tersier yaitu bahan yang memberikan petunjuk maupun penjelasan terhadap bahan hukum primer dan sekunder, contohnya kamus.

Teknik yang digunakan untuk pengumpulan bahan hukum yang diperlukan dalam penelitian ini diperoleh dengan cara melakukan studi kepustakaan dengan cara mencari, meringkas, mencatat dan mempelajari serta memahami buku-buku ilmiah yang memuat pendapat beberapa sarjana. Bahan hukum yang telah berhasil dikumpulkan tersebut selanjutnya akan dilakukan penyuntingan bahan hukum, pengklarifikasian bahan hukum yang relevan dan penguraian secara sistematis.

\section{Hasil Penelitian Dan Pembahasan}

\section{Perlindungan Hukum Bagi Para Pihak Dalam Perjanjian Jual Beli Melalui Media Internet}

Seperti biasanya kita mengenal jenis transaksi nyata dengan tatap muka langsung, dalam era cepat sepertinya hal itu dapat tidak dilakukan atau dapat dilakukan dengan cara lain yang lebih menghemat waktu dan tenaga. Seperti yang diketahui transaksi yang dilakukan menggunakan media online sebagai perantara merupakan hal yang sudah lumrah dilakukan saat ini. Perkembangan dunia elektronik yang semakin maju merupakan suatu alasan yang sangat besar melatarbelakangi perubahan komunikasi saat ini. Serasa tidak ada jarak yang memisahkan bahkan satu negara dengan negara lain terasa dekat dikarenakan perkembangan komunikasi dalam bidang elektronik saat ini.

Namun terdapat banyak masalah yang terjadi karena tidak semua orang mempunyai itikad baik dalam melakukan atau menggunakan media sosial yang ada. Banyak kasus penipuan yang terjadi terutama dalam bidang transaksi perdagangan yang melibatkan si penjual dengan pembelinya. Maraknya kasus penipuan yang terjadi di media internet saat ini lumayan meresahkan pengguna yang memang ingin berbuat baik.

Diterbitkannya UU mengenai perlindungan konsumen diharapkan bisa memberi solusi terhadap kejadian yang ada saat ini. UU tersebut dijadikan pelindung bagi konsumen yang dirugikan namun dalam hal ini diharapkan UU dapat menjadi keadilan bagi kedua belah pihak. Disini konsumen lebih dititik beratkan karena dalam posisi ini konsumen mempunyai kukuatan yang sangat lemah dibandingkan produsen atau pelaku usaha yang ada. 
Secara umum memberikan rasa aman, tentram dan sejahtera dan pengayoman baik hak dari setiap warga dan merupakan kewajiban yang dilaksanakan pemerintah yang berwenang demi menjaga negara agar tetap aman (HS, 2011).

Dalam hal ini UU dimaksudkan bukan untuk mematikan posisi pelaku usaha atau penggiat usaha, namun ini diharapkan agar menjadi sebuah transaksi yang sehat dan tidak bersifat monopoli atau menipu dikarenakan adanya beberapa oknum yang hanya ingin mencari keuntungan yang sebesar-besarnya tanpa peduli dengan apa yang dirasakan oleh konsumennya.

Konsumen harus pintar-pintar memilih dan jeli dalam proses pembelian secara tidak langgung ini. Harus dipikirkan secara perlahan jangan hanya karena tergoda dengan potongan harga lalu langsung asal pesan saja tanpa memikirkan resiko yang terjadi, biasanya bila berbelanja secara tidak langsung atau memesan dalam media sosial konsumen diharuskan membayar terlebih dahulu apabila konsumen sudah mentransfer uang yang sesuai dengan harga barang yang dibeli tersebut maka produes atau si penjual akan mengirimkan barang sesuai tempat alamat di pemesan tersebut. Suatu cara menghindarkan diri dari penipuan.

\section{Tanggung Jawab Penjual Dalam Perjanjian Jual Beli Barang Berdasarkan Pasal 1320 KUH Perdata}

Dalam KUH Perdata kegiatan pengikatan diri dengan seseorang atau lebih dalam menjalin sebuah hubungan bisnis merupakan arti dari sebuah perjanjian. Dalam hal ini diharapkan kedua belah pihak saling berpatokan pada persetujuan yang dirancang sejak awal dibentuknya.

Kegiatan transaksi perdagangan melaui media sosial zaman sekarang ini merupakan kebutuhan yang tidak bisa dihindarkan oleh masyarakat internasional umunya dan khususnya pada masyarakat Indonesia. Kecanduan akan proses yang cepat, mudah serta gampang mengakibatkan transaksi komersial berjalan sangan cepat.

Tanggung jawab yang dimiliki oleh si penjual disini diharapkan mampu melaksanakan sesuai dengan kewajibannya. Agar terhidar dari berbagai sengketa yang ada bisa sampai menyeret ke dalam penjara. Tanggung jawab disini maksudkan agar si penjual melaksanakan apa yang seharusnya dilakukan sesuai persetujuan yang dilakukan sejak awal transaksi (HS, 2011).

Masyarakat yang modern saat ini sudah cukup pintar dalam melakukan hubungan perdagangan melalui media yang ada sekarang ini. Gaya hidup dan tuntutan sosial menyebabkan maraknya terjadi penipuan yang menjadi korban disini ialah konsumen atau pemai hasil barang atau jasa yang ditawarkan.

Banyaknya kerugian yang ditimbulkan akibat dari perdagangan melalui media elektronik ini diharapkan pemerintah lebih tegas dalam melakukan perlindungan agar para pencari uang kotor tidak merajarela dipasaran. Pelaku usahapun dimohonkan guna melaksanakan kegiatan dengan berpatokan pada dasar kejujuran untuk melakukan suatu transaksi.

Adapun bentuk yang diberikan sebagai pertanggung jawaban oleh pengingat usaha atau yang menawarkan barang seandainya terjadi kesalahan ataupun barang yang dikirim cacat ataupun rusak dapat dilakukan dengan pengembalian uang atau penggantian barang yang baru itupun tergantung dari keputusan konsumen yang bersangkutan. Menanggung semua perbuatan yang diakibatkan merupakan definisi dari sebuah arti kata tanggung jawab. Terjadinya unsur kesalahan atau kesengajaan melakukan sesuatu yang merugikan dan membahayakan seseorang ataupun atas kehilangan barang atau sebagainya. Terjadinya kesalahan dalam pemakaian oleh pengguna menyebabkan kerugian yang dialami harus memperoleh tanggung jawab atas kegagalan suatu produk yang dihasilkan.

Kerugian yang ditimbulkan pihak lain atas kesalahan yang dilakukan haruslah sewajarnya mendapat pertanggungjawaban yang sesuai dengan derita yang dia tanggung atas kerugian tersebut. Banyak jenis ganti rugi yang bisa dilakukan oleh pelaku usaha mulai dari ganti rugi mengembalikan uang konsumen yang dirugikan sampai dengan ganti rugi dengan cara menanggung biaya yang dikeluarkan selama konsumen melakukan pengobatan jika terdapat kerusakan fatal yang terjadi pada fisik konsumen tersebut.

Pertanggungjawaban secara pidana merupakan sistem pertanggung jawaban menggunakan dua asas terpenting yaitu asas kesalahan dan asas legalistas dimana suatu pidana tidak ada bila tanpa adanya suatu kesalahan yang beriringan lurus. Pertanggungjawabannya berupa ancaman 
pidana penjara dan juga ancaman denda yang dijatuhkan kepada terdakwa yang bersalah dalam hal sengketa ini. Adapun apabila pelaku usaha melanggar larangan memperdagangkan barang/jasa yang tidak sesuai dengan janji yang dinyatakan dalam label, etiket, keterangan, iklan atau promosi penjualan barang dan/ jasa tersebut, maka pelaku usaha dapat dipidana berdasarkan Pasal 62 ayat (1) UU Perlindungan Konsumen.

\section{Simpulan}

Bantuan hukum yang diberikan kepada pengguna dan pelaksana kegiatan transaksi komersial, ketentuan dalam perjanjian ecommerce di Indonesia menimbulkan ketidak pastian hukum dan resiko yang tinggi bagi pelaku usaha lainnya. Bentuk dalam kontrak aktivitas electronic commerce pada hakekatnya disebut dengan online contract sangat berbeda dengan kontrak konvensional. Pelaksanaan kontrak dalam e-commerce pada umumnya terjadi antara para pihak yang berkedudukan berlainan negara atau kota, agar pelaksanaan kontrak komersil tidak mengalami hambatan, tentunya permasalahaan mengenai yuridiksi kewenangan pengadilan dalam menangani sengketa tersebut haruslah ditemukan pemecahan dan adanya aturan hukum yang pasti dalam pengaturannya.

Dalam transaksi komersial saat Ini perjanjian yang dilakukan dengan melalui media internet sebagai alat komunikasi. Berbagai kemudahan didapatkan dengan transaksi komersil tersebut. Namun dilain sisi terdapat berbagai masalah yang harus ditanggung keduanya atau orang yang melakukan perjanjian tersebut. Tanggung jawab bila terjadinya pelanggaran kewajiban harus mendapakan ganti rugi yang sesuai dengan yang telah disetujui sejak awal pembuatan persetujuan tersebut. Apabila terjadi sebuah sengketa dalam persetujuan tersebut dapat dilakukan dengan bantuan hukum yang ada saat ini pemerinah siap mengayomi masyakatnya sesuai peraturan yang ada. Seandainya bila tidak bisa dilakukan dalam hukum nasional bisa dilakukan dengan menggunakan hukum internasional yang mengatur mengenai konsumen yang bermasalah.

\section{Daftar Pustaka}

Agusta, E. R. (2010). Tanggung Jawab Penjual Dalam Perjanjian Jual Beli Barang Melalui Media Internet. Universitas Islam Indonesia, Yogyakarta.
Barkatullah, A. H., \& Prasetyo, T. (2005). Bisnis E-Commerce Studi Sistem Keamanan dan Hukum di Indonesia. Yogyakarta: Pustaka Pelajar.

HS, Salim. (2011). Pengantar Hukum Perdata Tertulis $(B W)$. Jakarta: Sinar Grafika.

Safi'i, I. M., \& Budiwati, S. (2018). Tanggung Jawab Para Pihak dalam Jual Beli Online Ditinjau dari Undang-Undang No 11 Tahun 2008 Tentang Informasi Transaksi Elektronik dan Undang Undang No 8 Tahun 1999 Tentang Perlindungan Konsumen. Universitas Muhammadiyah Surakarta. Retrieved from http://eprints.ums.ac.id/id/ eprint $/ 70264$

Kitab Undang-Undang Hukum Perdata.

Undang-Undang Dasar Negara Republik Indonesia Tahun 1945. 